\title{
Transfusion Practice in Surgical Resuscitation Department of a University Hospital, Antananarivo (Madagascar)
}

\author{
Rakotonomenjanahary Sidonie ${ }^{1 *}$, Razafindrainibe Tanjonirina ${ }^{2}$, Rahanitriniaina Nadia Marie Philibertine ${ }^{3}$, \\ Randriamandrato Tantely Anjarahaingo Voahangiarivola ${ }^{3}$ and Rajaonera Tovohery Andriambelo ${ }^{3}$ \\ ${ }^{1}$ Department of Anaesthesia and Intensive Care Unit of the Joseph Dieudonné Rakotovao University Hospital Centre (CHUJDR), Madagascar \\ ${ }^{2}$ Departments of Intensive Care Unit of Gynaecological and Obstetrics University Hospital Befelatanana (CHUGOB), Madagascar \\ ${ }^{3}$ Department of Intensive Care Unit of the Joseph Ravoahangy Andrianavalona University, Madagascar
}

*Corresponding author: Rakotonomenjanahary Sidonie, Department of Anaesthesia and Intensive Care Unit of the Joseph Dieudonné Rakotovao University Hospital Centre (CHUJDR), Madagascar

\begin{abstract}
Introduction: Given the frequency of blood transfusion in the intensive care unit, it must be performed according to the recommendations to ensure transfusion safety. The aim of our study is to describe the practice of transfusion in a surgical resuscitation service.

Methods: This is a 21-month retrospective and descriptive study (January 2015 - September 2016) in the Department of Surgical Resuscitation of the University Hospital JRA Antananarivo Madagascar. All patients over 15 years old and transfused during the study period are included.

Results: 937 patients were transfused, with a transfusion rate of $25.3 \%$. A male predominance (sex ratio $=2.21$ ) was found with an average age of $45.93( \pm 17.74)$ years. Digestive haemorrhage and postoperative cases are common reasons for transfusion. The blood count and the haemostasis assessment were performed in $58.38 \%$ and $50.48 \%$ of pre-transfusion patients, respectively. The red blood cell (RBC) is the most used (54.72\%), followed by Fresh Frozen Plasma (FFP) (28.68\%) and then there have been cases of use of Platelet - Rich Plasma (PRP) (12.93\%) and Whole Blood (2.67\%). The transfusion event occurred only in $0.43 \%$ of patients.

Conclusion: The realities of the country explain the insufficiency of biological arguments for transfusion. And the absence of a well-defined haemovigilance system makes transfusion accidents unrecognized and undeclared. Hence the interest of a transfusion protocol adapted to the Malagasy context.
\end{abstract}

\section{Introduction}

A blood crase disorder is a common occurrence in Intensive Care Unit (ICU) [1]. In general, it is anaemia or a haemostasis disorder. These disorders are at the same time the consequence of the initial pathology motivating the admission in resuscitation but also a factor of aggravation of the pre - existing pathology or the pathology responsible for the admission [2]. To correct these disorders, the use of transfusion is often necessary. But for a good practice of transfusion, like any therapeutic act, it must respect some recommendations [3]. So, this study was done in order to describe the practice of transfusion in intensive care unit of University Hospital /JRA, Antananarivo, Madagascar.

\section{Methods}

This is a descriptive, monocentric retrospective study performed in The Surgical Resuscitation Department of the Antananarivo University Hospital/JRA. It was conducted over 21 months from January 2015 to September 2016. All patients aged 15 years and over hospitalized in the department and who received a blood transfusion were included. The parameters analysed are: age, gender; the pathologies presented by the patient, the transfusion techniques, the type (Red Blood Cell (RBC), Fresh Frozen Plasma (FFP), Platelet-Rich Plasma (PRP), Whole Blood (WB)) and quantity (units) of labile blood products (LBP) transfused, the transfusion 
accidents, and the blood tests before and after transfusion (haemoglobin, platelet count, prothrombin level). The data were processed by the XLSTAT software version 2019 and the results are expressed as mean with standard deviation, minimum and maximum, and as a percentage.

\section{Results}

Table 1: General characteristics.

\begin{tabular}{|c|c|}
\hline Variables & Number (\%) \\
\hline Age & $45.93 \pm 17,74$ years \\
\hline \multicolumn{2}{|c|}{ Gender } \\
\hline Male & $645(68.83 \%)$ \\
\hline Female & $292(31.17 \%)$ \\
\hline \multicolumn{2}{|c|}{ Pathologies: } \\
\hline Digestive haemorrhage & $404(43.12 \%)$ \\
\hline PO digestive surgery & $151(16.11 \%)$ \\
\hline PO neurosurgery & $118(12.59 \%)$ \\
\hline PO thoracic and cardiovascular & $89(9.48 \%)$ \\
\hline surgery & $22(2.35 \%)$ \\
\hline PO urologic surgery & $12(1.28 \%)$ \\
\hline PO orthopaedic surgery & $141(15.05 \%)$ \\
\hline Other & $1866(54.72 \%)$ \\
\hline \multicolumn{2}{|c|}{ Type of LBP } \\
\hline RCB & $978(28.68 \%)$ \\
\hline FFP & $475(12.93 \%)$ \\
\hline PRP & $91(2.67 \%)$ \\
\hline WB & $4(0,43 \% \%)$ \\
\hline Transfusion accidents : & $3(0.32 \%)$ \\
\hline Urticarial & $1(0.11 \%)$ \\
\hline Other &
\end{tabular}

Of the 3700 patients hospitalized in the department during the study period, 937 patients $(25.3 \%)$ met the inclusion criteria. The average age of these transfused patients was 45.93 ( \pm 17.74 ) years; with a minimum age of 15 , the maximum age was 92 . The male gender was predominant ( 645 patients, $68.83 \%$, sex ratio $=2.21$ ). Digestive haemorrhages and post-operated cases held the top spots in the pathologies presented by these transfused patients, with $43.12 \%$ and $41.83 \%$ respectively. On the other hand, other pathologies (such as trauma, haemoptysis, haematuria, inflammatory anaemia, leukaemia, various tumours, shock conditions, etc.) were also significant as a reason for blood transfusion with a total of $15.05 \%$ (Table 1). Of the 937 patients transfused; before transfusion, $58.38 \%$ had a blood count and $50.48 \%$ had a haemostasis test; and after the transfusion, only $23.80 \%$ had a blood count and the haemostasis assessment was performed in $16 \%$ of the patients. The mean haemoglobin level ranged from $92.49( \pm 32.49) \mathrm{g} / \mathrm{l}$ during the pre-transfusion period to $105.78( \pm 22.27) \mathrm{g} / \mathrm{l}$ post transfusion. Mean pre-transfusion platelet count was $185.26( \pm 117.61)$ giga / l and $193.70( \pm 125.47)$ giga/l in post transfusion. The prothrombin level (PL) was $62.17( \pm 22.74) \%$ before transfusion and 67.13 ( \pm 20.26) \% after transfusion (Table 2). Simple transfusion accounted for $99.79 \%$ and transfusion exchange $0.21 \%$. The total amount of blood units received by the patients was 3410 with $54.72 \%$ red blood cell (RBC), $28.68 \%$ fresh frozen plasma (FFP), $12.93 \%$ platelet rich plasma (PRP) and 2.67\% Whole Blood (WB). Each patient receives on average 2 units of RBC, 1 unit of FFP, 0.5 unit of PRP (Figure 1). There were only 4 cases of transfusion accident including 3 urticarial and 1 dyspnoea andchills.

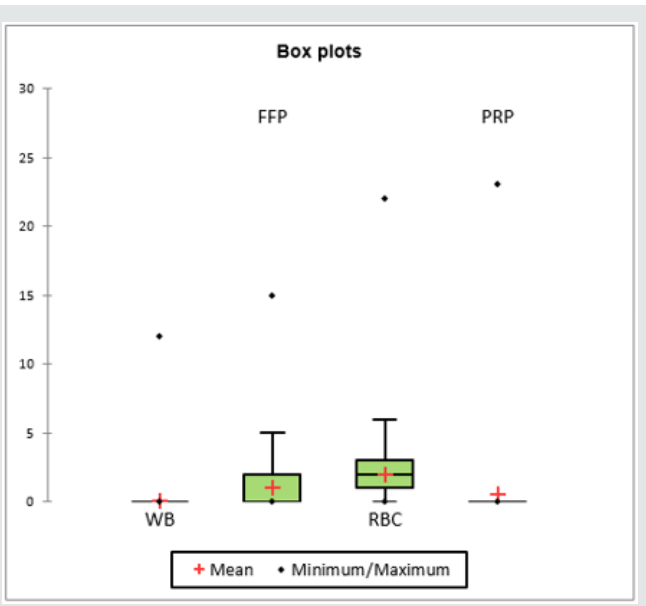

Figure 1: Variation of transfused LBPs.

Table 2: Evolution of biological test in pre and post transfusion.

\begin{tabular}{|c|c|c|c|c|c|c|}
\hline Statistic & Hb Pre & Hb Post & PLT Pre & PLT Post & PL Pre & PL Post \\
\hline Minimum & 11,00 & 28,00 & 4,00 & 3,00 & 2,90 & 17,60 \\
\hline Maximum & 221,00 & 165,00 & 875,00 & 789,00 & 100,00 & 100,00 \\
\hline Mean & 92,49 & 105,78 & 185,26 & 193,70 & 62,17 & 67,13 \\
\hline Standard deviation & 32,49 & 22,27 & 117,61 & 125,47 & 22,74 & 20,26 \\
\hline
\end{tabular}

Hb: Haemoglobin; PLT: Platelet; PL: Prothrombin Level; Pre: Pre-Transfusion; Post: Post Transfusion

\section{Discussion}

Resuscitation or intensive care unit is the place where admitted a patient whose vital function is at risk or likely to be. Haematological disorder can enter in this framework of vital function. And often, transfusion is necessary to correct these disturbances. In our case, the frequency of transfusion is $25.3 \%$. In other countries such as Ivory Coast, Denmark, and Canada, they have found transfusion frequency rates of $20 \%, 25 \%$, and $38 \%$ respectively [4-6]. And still according to these studies, these figures are quite high and a policy of reducing consumption of LBP deserves to be implemented. Regarding the profile of transfused patients, there is a male predominance with a low average age ( 45 years). Unlike those found in studies conducted in occidental countries where the average age is around 60 years $[7,8]$. The advantage of this 
relatively low age is the existence of low tolerance thresholds for anaemia; in general, the haemoglobin trigger is $70 \mathrm{~g} / \mathrm{l}$ for a young patient with no antecedent [9]. And for the pathologies presented by these transfused patients, these are the same etiologies that are reported in the literature; that is, trauma, heavy surgery and gastrointestinal bleeding, but of varying proportions [10]. And about the transfusion itself - apart from a simple transfusion, there is, but in a small proportion, the practice of transfusion exchanges in our case. Erythrocyte transfusion exchange is most often indicated during complications of sickle cell disease [11], which is similar to our case. And the use of CGR is the most common in our practice due to the frequency of anaemia during hospitalization in resuscitation. According to the literature, more than $55 \%$ of patients admitted to resuscitation have a haemoglobin level of less than $90 \mathrm{~g} / \mathrm{l}$ [10]. In our case, the average pre-transfusion haemoglobin level was $92.49 \mathrm{~g} /$ and there was a one-point post-transfusion gain for the haemoglobin level. It should be noted that the pre- and post-transfusion biological assessment rate in our practice is quite low. Since the biological assessment for deciding a transfusion or not is not always available, a study, similar to that carried out by Kranenburg FJ et al. [12] who sought predictive factors for transfusion, deserves to be instituted. This is in order to properly codify the transfusion practice by limiting the consumption of LBP and avoiding its complications. However, these complications can be dangerous and engage the prognosis of the patient [13]. In our case, the frequency rate of these complications is abnormally low. Three contingencies can explain this Figure 1, so that the frequency of these accidents is so low, it would require a quality technical platform and a good haemovigilance system; which is not our case. The other eventualities would be that other cases of transfusion complications exist but remain undeclared or unknown, hence the interest of protocolisation of transfusion safety [14].

\section{Conclusion}

This study allowed us to profile transfused patients and describe the practice of transfusion in a surgical resuscitation of a university hospital in Madagascar. In this time of LBP shortage [15], this study could improve transfusion practice not only by streamlining the use of PSLs, but also to limit transfusion accidents.

\section{References}

1. Corwin HL, Gettinger A, Pearl RG, Fink MP, Levy MM, et al. (2004) The CRIT Study: Anaemia and blood transfusion in the critically ill-Current clinical practice in the United States. Crit Care Med 32(1): 39-52.

2. Vincent J, Nguyenba V, Piagnerelli M (2003) Les pratiques transfusionnelles en réanimationTransfusion practices in the intensive care unit. Réanimation 12(8): 538-543.

3. Hebert $P$, Mcdonald B, Tinmouth A (2003) Conférence du XXXIe congrès de la SRLF. Transfusion en reanimation: Overview of transfusion practices in perioperative and critical care. Réanimation. mars 12(2): 160-170.

4. Coulibaly KT, N'da-Koffi NHC, N'guessan YF, Ouattara A,Mobio MP, et al. (2015) The anaemia in resuscitation's department: hematological, therapeutic and evolutionary aspects in the teaching hospital of Cocody (Ivory Coast). RAMUR 20(3): 19-23.

5. Jonsson AB, Rygård SL, Anhøj J, Johansson PI, Perner A, et al. (2019) Use of red blood cells in Danish intensive care units: A population-based register study. Acta Anaesthesiol Scand 63(10): 1357-1365.

6. Shehata N, Forster AJ, Lawrence N, Ducharme R, Fergusson DA (2015) Transfusion Patterns in all patients admitted to the ICU and in those who die in hospital: a descriptive analysis. PLoS ONE 10(9): e0138427.

7. Vakalos A, Popko V (2015) Correlation between FFP transfusion and age in ICU patients. Intensive Care Medecine Experimental 3 (Suppl 1): A379.

8. Vincent JL, Ulrich Jaschinski U, Wittebole X, Lefrant JY, Jakob SM, et al. (2018) Worldwide audit of blood transfusion practice in critically ill patients. Critical Care 22(1): 102.

9. Piagnerelli M, Vincent J (2008) Evaluation of the transfusional threshold in critically ill patients. juin 17(4): 318-325.

10. Huet O, Duranteau J (2003) The natural history of aneamia in ICU patient. Réanimation 12(8): 544-548.

11. Couëc, ML (2012) Transfusion in children with sickle cell disease. Transfus Clin Biol 19(4-5): 142-144.

12. Kranenburg FJ, le Cessie S, Caram-Deelder C, van der Bom JG, Arbous MS (2019) Determinants of transfusion decisions in the ICU: haemoglobin concentration, what else? - a retrospective cohort study. Vox Sang.

13. Delaney M, Wendel S, Bercovitz RS, Cid J, Cohn C, et al. (2016) Transfusion reactions: prevention, diagnosis, and treatment. The Lancet 388(10061): 2825-2836.

14. Reynaert D, Desmoineaux C, Guinaudeau L (2019) Virtual reality, a safety tool for nursing care in transfusion practice. Soins 64 (837): 41-44.

15. Tissot JD, Danic B, Schneider T (2015) Transfusion sanguine: en toute sécurité d'approvisionnement. Presse Med.

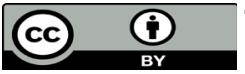

This work is licensed under Creative Commons Attribution 4.0 License

To Submit Your Article Click Here:

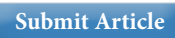

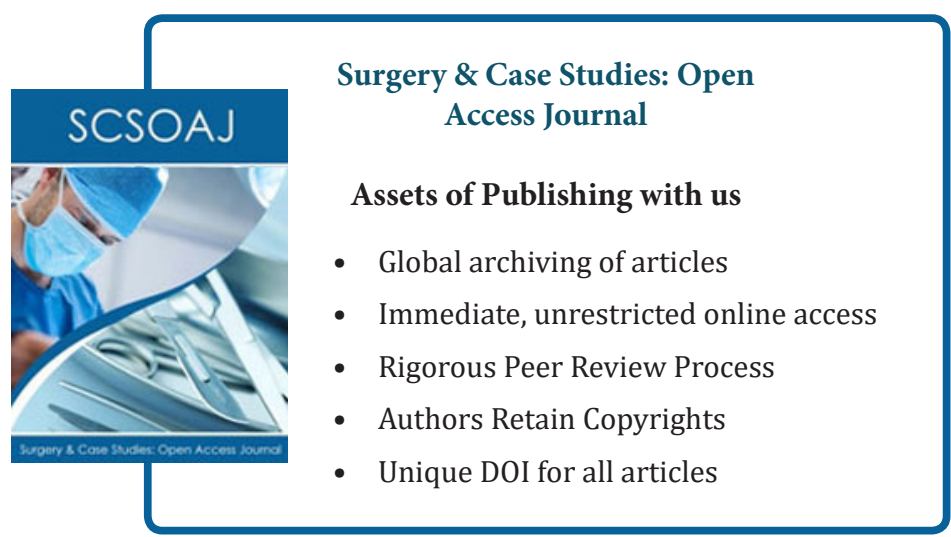

Citation: Rakotonomenjanahary S, Razafindrainibe T, Rahanitriniaina Nadia M P, Randriamandrato Tantely AV, Rajaonera Tovohery A. 